\title{
Metabolic Response of 'Topaz' Apple Fruit to Minimal Application of Nitrogen during Cell Enlargement Stage
}

\author{
Jerneja Jakopic $^{1}{ }^{1}$, Valentina Schmitzer ${ }^{2, *}$, Robert Veberic ${ }^{1}\left(\mathbb{D}\right.$, Tina Smrke ${ }^{1}\left(\mathbb{D}\right.$ and Franci Stampar ${ }^{1}$ \\ 1 Department of Agronomy, Biotechnical Faculty, University of Ljubljana, SI-1000 Ljubljana, Slovenia; \\ jerneja.jakopic@bf.uni-lj.si (J.J.); robert.veberic@bf.uni-lj.si (R.V.); tina.smrke@bf.uni-lj.si (T.S.); \\ franci.stampar@bf.uni-lj.si (F.S.) \\ 2 Department of Landscape Architecture, Biotechnical Faculty, University of Ljubljana, \\ SI-1000 Ljubljana, Slovenia \\ * Correspondence: valentina.schmitzer@bf.uni-lj.si; Tel.: +386-1320-3076
}

check for updates

Citation: Jakopic, J.; Schmitzer, V.; Veberic, R.; Smrke, T.; Stampar, F. Metabolic Response of 'Topaz' Apple Fruit to Minimal Application of Nitrogen during Cell Enlargement Stage. Horticulturae 2021, 7, 266. https://doi.org/10.3390/ horticulturae7090266

Academic Editors: Wilfried Rozhon and Sabine von Tucher

Received: 12 August 2021

Accepted: 23 August 2021

Published: 26 August 2021

Publisher's Note: MDPI stays neutral with regard to jurisdictional claims in published maps and institutional affiliations.

Copyright: (c) 2021 by the authors. Licensee MDPI, Basel, Switzerland. This article is an open access article distributed under the terms and conditions of the Creative Commons Attribution (CC BY) license (https:// creativecommons.org/licenses/by/ $4.0 /)$.

\begin{abstract}
Nitrogen is an integral element of foliar sprays during apple fruit formation. However, in red cultivars, the application may have adverse effects on color in the second stage of fruit development. The effect of a low-dose foliar application of urea was monitored on 'Topaz' apple pomometric (fruit mass, firmness, total solids, starch content, skin color) and biochemical traits (primary metabolites, phenolic compounds, and assimilatory pigments). Three applications (17 July, 27 July, and 18 August) of two different urea doses ( $\mathrm{N} 1=1.4 \mathrm{~kg} \mathrm{~N} \mathrm{ha}^{-1} ; \mathrm{N} 4=4 \mathrm{~kg} \mathrm{~N} \mathrm{ha}^{-1}$ ) and control (N0, only sprayed with water) were used. Low doses of urea did not affect flesh firmness, total soluble, solid, and starch content, but individual fruit mass was significantly higher in N1 treatment compared to the other two treatments. Significantly lower $\mathrm{a}^{*}$ parameters and a lower content of anthocyanins were measured on apples subject to N4 treatment. Many secondary metabolites (phenolic acids, flavan-3-ols, flavonols, and chalcones) were also negatively affected by low-dose urea application. Conversely, urea treatments significantly increased total assimilatory pigments in apple skin. Even minor levels of nitrogen, applied directly on the leaf at later stages of red apple fruit development, negatively altered color traits and the composition of metabolites.
\end{abstract}

Keywords: Malus domestica; foliar urea; sugars; organic acids; phenolics; anthocyanins; assimilatory pigments

\section{Introduction}

Nitrogen is one of the key macronutrients regulating the growth and development of all plants, including apple fruit trees in production orchards. Its availability is linked to vegetative growth as well as to a general increase in biomass, leading to improved plant productivity and fruit yield [1]. Xia et al. [2] demonstrated that increased N supply improved leaf $\mathrm{N}$ status and photosynthetic activity generating faster cell proliferation and consequently, larger 'Gala' apples. However, nitrogen nutrients added at specific stages of a plant's development may inhibit the biosynthesis of selected groups of secondary metabolites [3]. These compounds are associated with several major quality traits of apple cultivars and play an important role in plant defense mechanisms [4].

A decisive factor influencing consumer choices is the intense color of apple skin [5,6], particularly of red apple cultivars. Visually perceived red hues are directly linked to the accumulation of anthocyanins (a group of secondary metabolites) in fruit skin. The content of these pigments depends on several factors, initially on the genetic predisposition of a particular cultivar but also on numerous external elements. The latter can be grouped into soil conditions, climatic factors, diverse stressors (abiotic and biotic), as well as to various technological practices [7].

As nitrogen is an essential mineral nutrient affecting the growth, yield, and fruit quality of apples, detailed nitrogen fertilization plans are followed in high-production orchards [8]. 
This nutrient is added to the soil or applied in the form of foliar fertilizers. This measure is implemented several times throughout the season starting from late June until the final week before harvest with the aim of improving apple fruit firmness, shelf life, as well as preventing some storage disorders [9-11]. Moreover, low-level nitrogen fertilizers are added on-leaf to quickly alleviate sudden nutrient deficiencies as they are readily available to the plant [12]. In most cases, urea is used as a source for foliar fertilization. It is highly soluble in water, rapidly absorbed by plants, and rarely exhibits signs of phytotoxicity [13]. During the fruit set and apple fruit cell division stage, the application of urea sprays is a positive measure in most apple cultivars [14]. In later stages of fruit enlargement, red apple cultivars may be adversely affected by foliar application of nitrogen as it disturbs the synthesis of anthocyanin pigments and consequently, red skin coloration [15].

Few comprehensive compositional studies have been aimed to elucidate the potential negative effects of foliar addition of low levels of urea on apple phenolic status. Wang and Cheng [16] have determined a negative correlation between nitrogen supply and skin pigmentation of 'Gala' apples and measured a decrease in total anthocyanin levels in fruit skin. Similarly, Reay et al. [17] measured decreased total anthocyanin levels in urea-treated 'Gala' apples. On the other hand, visual assessment of 'Fuji' apples subject to different urea treatments was inconclusive to the effect of nitrogen on color formation [12]. Unfavorable color traits of pomegranate fruit have also been linked to foliar nitrogen fertilization [18]. These authors have additionally studied nitrogen-induced alterations in carotenoid and chlorophyll content levels, but up until now, no research has focused on other groups of secondary metabolites.

The aim of the present study was, therefore, to define metabolic changes induced by low doses of nitrogen-containing foliar sprays applied several times during the fruit cell enlargement stage. A detailed primary and secondary profile of 'Topaz' apple at harvest was established to determine possible negative effects of low nitrogen spraying on the internal quality of red apple cultivars. Additionally, the effect of urea spraying on assimilatory pigments in fruit skin was discussed.

\section{Materials and Methods}

\subsection{Plant Material and Experimental Design}

The study was performed in 2018 on 4-year-old full-bearing apple trees cv. 'Topaz', grafted on an M9 rootstock, growing at the experimental orchard of the Biotechnical Faculty, Ljubljana (latitude $46.06 \mathrm{~N}$, longitude $14.51 \mathrm{E}$, altitude $295 \mathrm{~m}$ ). The planting distance was $3.5 \times 1 \mathrm{~m}$, the rows were N-S oriented, and the trees were pruned to a slender spindle. The space between the rows was covered with grass and the orchard was managed according to the integrated production practices. Chemical thinning was completed prior to the experiment and hand correction to 7 fruit per $\mathrm{cm}^{2}$ trunk cross-section area (TCA) was performed. The experiment consisted of three on-tree applications (17 July, $27 \mathrm{July}$, and 18 August) of two different $\mathrm{N}$ doses $\left(\mathrm{N} 1=1.4 \mathrm{~kg} \mathrm{~N} \mathrm{ha}^{-1} ; \mathrm{N} 4=4 \mathrm{~kg} \mathrm{~N} \mathrm{ha}^{-1}\right)$ and control (N0, only sprayed with water). Folur (urea-based foliar spray, $22 \% w / v \mathrm{~N}$ ) was used for on-leaf application. At each application, trees were sprayed to the drip point. Each treatment consisted of eight representative trees $(n=8)$ and was separated in the row by three guard trees. Other technological measures in the orchard did not differ among treatments (irrigation, lighting conditions, hail net cover, soil nutrition, etc.).

\subsection{Sampling and Basic Fruit Analyses}

All fruit from each tree were harvested at technological maturity and subjected to basic quality analyses. Fruits were counted and total fruit mass per tree was recorded. Five (5) uniform fruits per tree were subjected to ripeness tests ( 40 fruit per treatment) and chemical analyses (combined sample included all five fruits from a single tree, $n=5$ ). Specifically, fruit mass and firmness were recorded, the latter with a penetrometer equipped with a $9 \mathrm{~mm}$ tip. Total soluble solids were measured $\left({ }^{\circ} \mathrm{Bx}\right)$ and starch content was evaluated according to the starch-iodine test on a scale of 0 to 5 . Apple skin color was measured at 
three sampling dates (17 July, 6 August, 24 September) on two opposite sides on each fruit with a portable colorimeter (CR-10 Plus, Konica Minolta, Osaka, Japan), which defines parameters in Commission International de l'Eclairage (CIE) system of color representation. Luminescence $\mathrm{L}^{*}\left(0=\right.$ black, $100=$ white), $\mathrm{a}^{*}$ and $\mathrm{b}^{*}$ values (green to red and blue to yellow $)$ and $\mathrm{h}^{\circ}\left(0^{\circ}=\right.$ red, $90^{\circ}=$ yellow, $180^{\circ}=$ green and $360^{\circ}=$ blue $)$ were assessed to define differences among treatments. For all basic analyses, five repetitions were carried out $(n=5)$ per treatment and five fruits from each tree were assessed to form a single repetition. Fruit segments (separately for each repetition) were chopped, and a portion of the combined sample was used for the analyses of primary metabolites. Phenolic compounds and assimilatory pigments were analyzed in the fruit skin of the same apples.

\subsection{Extraction and Determination of Sugars and Organic Acids}

For the quantification of primary metabolites, a section of fruit with skin (5 g) was ground to a pulp with $25 \mathrm{~mL}$ of double distilled water using an Ultra-Turrax T-25 (IkaLabortechnik). Extraction was performed at room temperature with constant stirring for $30 \mathrm{~min}$ [19]. The supernatant was centrifuged (Eppendorf Centrifuge $5810 \mathrm{R}$ ) at 10,621 $\times g$ for $10 \mathrm{~min}$ at $10^{\circ} \mathrm{C}$ and filtered through a $0.20 \mu \mathrm{m}$ cellulose ester filter (Macherey-Nagel, Germany) into a vial. Primary metabolites were analyzed on a high-performance liquid chromatography (HPLC) system (Thermo Separation Products, San Jose, CA, USA). The injection volume was $20 \mu \mathrm{L}$ and a flow rate of $0.6 \mathrm{~mL} \mathrm{~min}^{-1}$ was maintained during the total run time (30 $\mathrm{min})$. Sugars were separated on a Rezex RCM-monosaccharide column $\mathrm{Ca}+(300 \mathrm{~mm} \times 7.8 \mathrm{~mm})$ (Phenomenex) operated at $65^{\circ} \mathrm{C}$. Double distilled water was used as a mobile phase and a refractive index (RI) detector for carbohydrate identification [19]. Organic acids were detected on the same HPLC system. PDA detector was set at $210 \mathrm{~nm}$ and a Rezex ROA-organic acid H+ column (Phenomenex) $(300 \mathrm{~mm} \times 7.8 \mathrm{~mm})$ was used for metabolite separation [19]. The column temperature was set at $65^{\circ} \mathrm{C}$ and $4 \mathrm{mM}$ sulphuric acid in double-distilled water was used for the mobile phase.

Sugars and organic acids contents were calculated with the help of corresponding external standards and expressed in $\mathrm{mg} \mathrm{g}^{-1}$ (sugars) or $\mu \mathrm{g} \mathrm{g}^{-1}$ (organic acids) fresh weight (FW). Total sugar content and total organic acids content were calculated as the sum of identified individual sugars or organic acids.

\subsection{Extraction and Determination of Phenolic Compounds}

Fruit skin $(1.0 \mathrm{~g})$ was chopped and extracted with $5 \mathrm{~mL}$ methanol containing 3\% $(v / v)$ formic acid in an iced ultrasonic bath for $1 \mathrm{~h}$ [19]. After extraction, the extracts were centrifuged for $10 \mathrm{~min}$ at $10,621 \times g$ at $4{ }^{\circ} \mathrm{C}$, filtered through a $0.2 \mu \mathrm{m}$ Chromafil AO-20/25 polyamide filter (Macherey-Nagel, Germany) and transferred to a vial prior to injection into the HPLC system. Identification of individual phenolic compounds was performed on a Thermo Scientific Dionex HPLC system (Thermo Scientific, San Jose, CA, USA) coupled with a diode array detector at $280 \mathrm{~nm}, 350 \mathrm{~nm}$, and $530 \mathrm{~nm}$. A $150 \times 4.6 \mathrm{~mm}$, $3 \mu \mathrm{m}$, Gemini C18 (Phenomenex, Torrance, CA, USA) operated at $25^{\circ} \mathrm{C}$ was used. The injection volume was $20 \mu \mathrm{L}$ and the flow rate was maintained at $0.6 \mathrm{~mL} \mathrm{~min}^{-1}$. The elution solvents were (A) $3 \%$ acetonitrile with $0.1 \%$ formic acid in double-distilled water and (B) $3 \%$ double-distilled water with $0.1 \%$ formic acid in acetonitrile. A linear gradient was adapted from Tomic et al. [20]. In brief, 0-15 min, 5\% solvent B; 15-20 min, 20\% B; $20-30 \mathrm{~min}, 30 \% \mathrm{~B} ; 30-35 \mathrm{~min}, 90 \% \mathrm{~B}$; and $35-45 \mathrm{~min}, 100 \% \mathrm{~B}$ before returning to the initial conditions to the end of the run time. The column was equilibrated for $5 \mathrm{~min}$ between samples. All phenolic compounds were identified using a mass spectrometer (Thermo Scientific, LCQ Deca XP MAX) with electrospray ionization (ESI) operating in negative ion mode (all phenolic groups except for anthocyanins) and positive ion mode (anthocyanins) on an HPLC/MS system. Detailed procedures are described by Tomic et al. [20]. Compounds were determined according to their retention times, spectral and fragmentation characteristics, and by adding authentic standards to the samples. The content levels were calculated from peak areas and calibration curves of corresponding 
external standards or similar compounds (if standards were not available) and expressed in $\mu \mathrm{g} \mathrm{g}^{-1} \mathrm{FW}$.

\subsection{Extraction and Determination of Assimilatory Pigments}

Chloroplast pigments (carotenoids, chlorophylls) were extracted from apple skin $(1.5 \mathrm{~g})$ with $2 \mathrm{~mL}$ ice-cold acetone under dimmed light as described by Sircelj and Batic [21]. An HPLC system with a DAD detector set at $450 \mathrm{~nm}$ equipped with a Gemini C18 column was used for initial identification and quantification. The temperature was set at $25^{\circ} \mathrm{C}$ and the flow rate was maintained at $1 \mathrm{~mL} \mathrm{~min}^{-1}$. The gradient was as follows: from $10 \% \mathrm{~B}$ to $70 \% \mathrm{~B}$ in the first $18 \mathrm{~min}$, then linearly to $70 \% \mathrm{~B}$ to $22 \mathrm{~min}$ and returning to the initial conditions to the end of the run. Mobile phase A was acetonitrile, double-distilled water, and methanol $(100 / 10 / 5 ; v / v / v)$ and mobile phase $B$ was acetone with ethyl acetate $(2 / 1 ; v / v)$.

Individual chloroplast pigments were further identified on a TSQ Quantum Access Max quadrupole mass spectrometer as previously described by Senica et al. [22]. The chromatographic conditions were the same as described above. The MS instrument was operated using an atmospheric pressure chemical ionization (APCI) source in positive ion mode. The APCI parameters were as follows: vaporizer temperature $450{ }^{\circ} \mathrm{C}$, capillary temperature $320^{\circ} \mathrm{C}$, corona voltage $4.0 \mathrm{kV}$, sheat gas $55 \mathrm{~L} / \mathrm{h}$, auxiliary gas $10 \mathrm{~L} / \mathrm{h}$. Mass spectra were scanned in the range from $m / z 70$ to 650 and argon was used as the collision gas. Data acquisition was performed using Xcalibur 2.2 software. Identification was achieved with mass spectra scans, fragmentation, retention times, and spectral properties of target compounds and all compounds were expressed in $\mu \mathrm{g} \mathrm{g}^{-1} \mathrm{FW}$.

\subsection{Chemicals}

Analytical grade extraction solvents (methanol, acetone, and acetonitrile) were obtained from Sigma-Aldrich Corp. (St Luis, MO, USA). Purified water was obtained with Milli-Q Direct 8 system by Millipore (Merck KGaA, Darmstadt, Germany).

For identification and quantification of primary metabolites sucrose, fructose, glucose, sorbitol, and citric, malic, quinic, and fumaric acids were purchased from Fluka Chemie (Buchs, Switzerland) and shikimic acid from Sigma-Aldrich Chemicals (St. Louis, MO, USA).

For identification and quantification of phenolic compounds and chloroplast pigments, the following standards were used: procyanidin B1, (+)-catechin, quercetin-3-O-galactoside, quercetin-3-O- rhamnoside, phloretin, and cyanidin-3-galactoside from Fluka (Buchs, Switzerland), chlorogenic acid, quercetin-3-O-xyloside, and quercetin-3-O-rutinoside from Sigma-Aldrich Chemie GmbH (Steinheim, Germany) and quercetin-3-O-arabinopyranoside and quercetin-3-arabinofuranoside from Apin Chemicals LTD (Abingdon, UK). Lutein, chlorophyll a and chlorophyll b, $\alpha$-carotene, and $\beta$-carotene were obtained from DHI Lab (Hørsholm, Denmark).

\subsection{Data Analysis}

Statistical analysis was performed with the Statgraphics Plus 4.0 (Manugistics, Rockville, MD, USA) program using a one-way analysis of variance (ANOVA). The LSD multiple range test was used to determine the differences in analyzed parameters and phenolic groups/individual compounds among different treatments $(p<0.05)$. Results are presented as the mean values with standard error.

\section{Results and Discussion}

\subsection{Basic Fruit Analyses}

Pomometric analyses revealed non-significant effects of low doses of urea on flesh firmness, dry matter, and starch content. However, individual fruit mass was significantly higher in the N1 treatment compared to the other two treatments (Table 1). This is in line with the study of Xia et al. [2], who demonstrated a tight correlation between increased 
nitrogen supply and larger 'Gala' apples but only within the range of $\mathrm{N}$ supply used by the trees. Correspondingly, Davarpanah et al. [18] measured the increased average fruit weight of pomegranate in a low-dose-urea application. In N4 treatment, the average size of 'Topaz' apples was not significantly higher compared to untreated apple trees. Previous studies also report inconsistent results on the impact of increased nitrogen application on apple fruit size [23], particularly if the $\mathrm{N}$ status is not limiting to the tree growth.

Table 1. Fruit weight (g), flesh firmness $\left(\mathrm{kg}\right.$ per $\left.\mathrm{cm}^{2}\right)$, dry matter $\left({ }^{\circ} \mathrm{Bx}\right)$, and starch content (visual scale 0-5) at harvest and color parameters of 'Topaz' apples during the experimental period subject to three urea treatments.

\begin{tabular}{|c|c|c|c|c|}
\hline & No & N1 & N4 & Significance \\
\hline \multicolumn{5}{|l|}{17 July } \\
\hline $\mathrm{L}^{*}$ & $56.9 \pm 1.9$ & $56.6 \pm 0.6$ & $58.8 \pm 0.5$ & NS \\
\hline$a^{*}$ & $-3.5 \pm 0.7$ & $-1.5 \pm 1.1$ & $-2.7 \pm 0.9$ & NS \\
\hline$b^{*}$ & $40.3 \pm 0.5$ & $38.9 \pm 0.8$ & $40.7 \pm 0.6$ & NS \\
\hline $\mathrm{C}$ & $40.5 \pm 0.5$ & $38.9 \pm 0.8$ & $41.0 \pm 0.7$ & NS \\
\hline $\mathrm{h}^{\circ}$ & $94.3 \pm 1.2$ & $91.4 \pm 1.6$ & $93.0 \pm 0.8$ & NS \\
\hline \multicolumn{5}{|l|}{8 August } \\
\hline $\mathrm{L}^{*}$ & $62.8 \pm 0.4$ & $63.2 \pm 0.5$ & $62.3 \pm 0.5$ & NS \\
\hline$a^{*}$ & $-9.6 \pm 0.2$ & $-9.8 \pm 0.1$ & $-9.8 \pm 0.1$ & NS \\
\hline$b^{*}$ & $42.9 \pm 0.4$ & $43.3 \pm 0.5$ & $43.3 \pm 0.4$ & NS \\
\hline $\mathrm{C}$ & $43.9 \pm 0.4$ & $44.4 \pm 0.5$ & $44.5 \pm 0.5$ & NS \\
\hline$h^{\circ}$ & $102.5 \pm 0.3$ & $102.8 \pm 0.2$ & $102.8 \pm 0.2$ & NS \\
\hline \multicolumn{5}{|l|}{24 September } \\
\hline $\mathrm{L}^{*}$ & $42.0 \pm 0.9 \mathrm{a}$ & $43.8 \pm 0.9 \mathrm{a}$ & $46.8 \pm 0.9 \mathrm{~b}$ & * \\
\hline$a^{*}$ & $33.5 \pm 0.6 c$ & $29.8 \pm 0.7 b$ & $27.7 \pm 0.9 \mathrm{a}$ & * \\
\hline$b^{*}$ & $20.0 \pm 0.5 \mathrm{a}$ & $21.0 \pm 0.7 \mathrm{a}$ & $23.2 \pm 0.6 \mathrm{~b}$ & * \\
\hline $\mathrm{C}$ & $39.0 \pm 0.6 b$ & $36.7 \pm 0.5 \mathrm{a}$ & $36.1 \pm 0.6 \mathrm{a}$ & * \\
\hline$h^{\circ}$ & $30.5 \pm 0.9 \mathrm{a}$ & $34.8 \pm 1.2 \mathrm{~b}$ & $39.2 \pm 1.3 c$ & $*$ \\
\hline Fruit Firmness & $7.5 \pm 0.2$ & $6.9 \pm 0.3$ & $7.4 \pm 0.2$ & NS \\
\hline Dry Matter & $13.2 \pm 0.5$ & $12.8 \pm 0.2$ & $12.9 \pm 0.3$ & NS \\
\hline Starch content & $3.7 \pm 0.2$ & $3.8 \pm 0.3$ & $0.8 \pm 0.3$ & NS \\
\hline Fruit Weight & $147.0 \pm 6.1 \mathrm{a}$ & $170.7 \pm 7.3 b$ & $149.0 \pm 3.1 \mathrm{a}$ & $*$ \\
\hline
\end{tabular}

Treatments: N0 = sprayed with water only, N1 $=1.4 \mathrm{~kg} \mathrm{~N} \mathrm{ha}^{-1}, \mathrm{~N} 4=4 \mathrm{~kg} \mathrm{~N} \mathrm{ha}^{-1}$. Different letters (a,b,c; NS, non-significant, * significant difference at $p<0.05)$ for each parameter denote statistically significant differences among treatments by LSD multiple range test.

Apple skin color is an influential parameter of external fruit quality which frequently determines market acceptance [6]. It is primarily regulated by the relative levels of anthocyanin, chlorophyll, and carotenoid pigments in fruit skin $[7,24]$. The color measurements were performed on three separate dates, but the effect of urea treatment was only significant on the last sampling (Table 1 ). Considerably lower $\mathrm{a}^{*}$ parameters were measured on the surface of apples subject to $\mathrm{N} 4$ treatment suggesting less intense red coloration of their skin (Figure 1). Moreover, N0 and N1 treatments resulted in apples, which were characterized by significantly darker fruit color (lower $\mathrm{L}^{*}$ parameters) and lower hue $\left(\mathrm{h}^{\circ}\right)$ compared to N4 treatment. The latter depicts different shades of color with $0^{\circ}$ being absolute red. A negative influence of higher levels of nitrogen on the color formation of fruit skin has previously been reported for 'Gala' and 'Jonagold' apples [17,25] as well as on mango [26], grape [27], and peach [28]. 


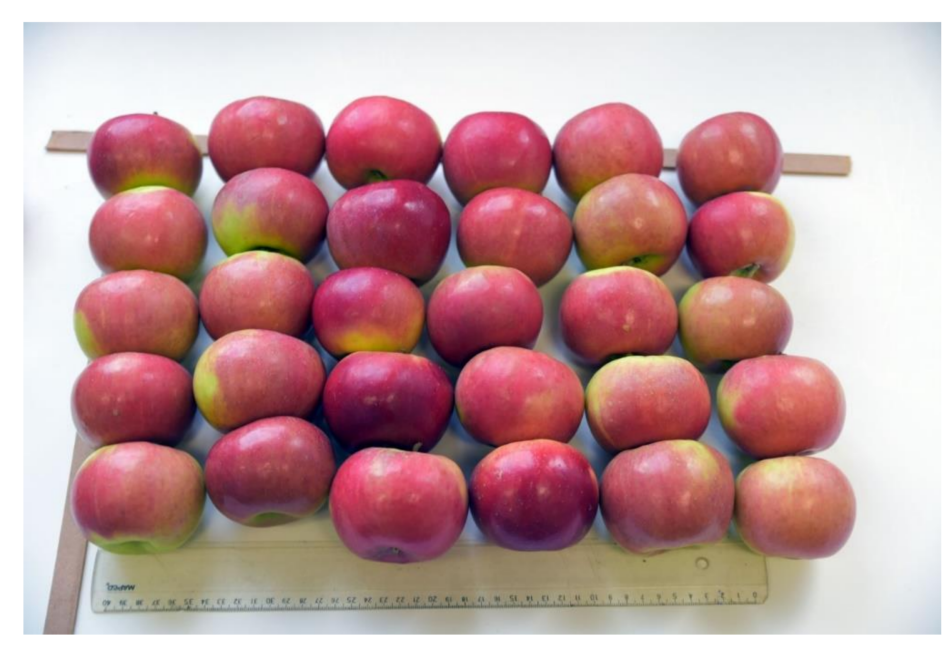

Figure 1. 'Topaz' apples at harvest subject to three treatments: $\mathrm{N} 1=1.4 \mathrm{~kg} \mathrm{~N} \mathrm{ha-1}$ (left 10), $\mathrm{N} 0=$ sprayed with water only (middle 10), N4 $=4 \mathrm{~kg} \mathrm{~N} \mathrm{ha}^{-1}$ (right 10).

\subsection{Sugars and Organic Acids}

Four individual sugars (sucrose, fructose, glucose, and sorbitol) and four organic acids (malic, citric, shikimic, and fumaric acid) were quantified in 'Topaz' fruit (Table 2) at harvest and significant differences in their content were detected among treatments except for major organic acids (Table 2). The composition of apple fruit is in line with detailed reports on apple fruit metabolic profile [29-31]. The highest levels of individual sugars, as well as their sum, were measured in N0 and N1 treatments. A similar outcome of nitrogen fertilization was reported for tomatoes as low nitrogen supply increased their sugar content as well as decreased the levels of organic acids [32,33]. Nitrogen is required to allow carbohydrates to be utilized for growth [34] and higher amounts of this essential nutrient may be linked to the larger size of N4-treated 'Topaz' apples.

Table 2. Primary metabolites (sugars $\mathrm{mg} \mathrm{g}^{-1} \mathrm{FW}$; organic acids $\mu \mathrm{g} \mathrm{g}^{-1} \mathrm{FW}$ ) of 'Topaz' apples subject to three urea treatments.

\begin{tabular}{ccccc}
\hline Compound & N0 & N1 & N4 & Significance \\
\hline Sucrose & $40.0 \pm 1.2$ & $36.6 \pm 0.7$ & $36.8 \pm 1.4$ & NS \\
Glucose & $13.4 \pm 0.5 \mathrm{~b}$ & $13.2 \pm 0.6 \mathrm{~b}$ & $10.8 \pm 0.9 \mathrm{a}$ & $*$ \\
Fructose & $39.0 \pm 0.4 \mathrm{~b}$ & $39.3 \pm 0.4 \mathrm{~b}$ & $35.8 \pm 0.3 \mathrm{a}$ & $*$ \\
Sorbitol & $2.0 \pm 0.2 \mathrm{~b}$ & $1.6 \pm 0.0 \mathrm{a}$ & $1.3 \pm 0.1 \mathrm{a}$ & $*$ \\
Total sugars & $94.4 \pm 2.2 \mathrm{~b}$ & $90.6 \pm 0.9 \mathrm{~b}$ & $84.6 \pm 2.7 \mathrm{a}$ & $*$ \\
\hline Citric acid & $119.5 \pm 10.8$ & $110.7 \pm 3.7$ & $108.7 \pm 10.7$ & $\mathrm{NS}$ \\
Malic acid & $9642.9 \pm 420.4$ & $8398.1 \pm 237.3$ & $8367.2 \pm 450.4$ & $\mathrm{NS}$ \\
Shikimic acid & $3.8 \pm 0.4$ & $3.6 \pm 0.2$ & $3.5 \pm 0.4$ & $\mathrm{NS}$ \\
Fumaric acid & $0.4 \pm 0.0 \mathrm{~b}$ & $0.3 \pm 0.0 \mathrm{a}$ & $0.3 \pm 0.2 \mathrm{a}$ & $*$ \\
Total organic acids & $9766.5 \pm 430.4$ & $8512.7 \pm 237.6$ & $8479.7 \pm 460.3$ & NS \\
\hline
\end{tabular}

Treatments: $\mathrm{N} 0=$ sprayed with water only, $\mathrm{N} 1=1.4 \mathrm{~kg} \mathrm{~N} \mathrm{ha}^{-1}, \mathrm{~N} 4=4 \mathrm{~kg} \mathrm{~N} \mathrm{ha}^{-1}$. Different letters (a,b; NS, non-significant, ${ }^{*}$ significant difference at $\left.p<0.05\right)$ for each parameter denote statistically significant differences among treatments by LSD multiple range test.

\subsection{Individual Phenolic Compounds}

Detailed profiling of technologically mature 'Topaz' apple at harvest revealed the presence of two phenolic acids, seven flavonols, three chalcones, and three anthocyanins (Table 3 ) which is in line with the reports on other apple cultivars $[35,36]$. 
Table 3. Phenolic compounds ( $\mu \mathrm{g} \mathrm{g}^{-1} \mathrm{FW}$ ) of 'Topaz' apples subject to three urea treatments.

\begin{tabular}{|c|c|c|c|c|}
\hline Compound & No & N1 & N4 & Significance \\
\hline$p$-coumaroyl glucoside & $9.9 \pm 1.8$ & $6.2 \pm 0.7$ & $6.7 \pm 0.5$ & NS \\
\hline Chlorogenic acid & $60.9 \pm 2.5 b$ & $48.2 \pm 4.9 \mathrm{a}$ & $47.7 \pm 1.4 \mathrm{a}$ & $*$ \\
\hline Total phenolic acids & $70.7 \pm 4.3 \mathrm{~b}$ & $54.7 \pm 5.6 \mathrm{a}$ & $54.4 \pm 1.9 \mathrm{a}$ & * \\
\hline Catechin & $187.6 \pm 8.7 \mathrm{~b}$ & $128.5 \pm 6.3 \mathrm{a}$ & $131.2 \pm 7.7 \mathrm{a}$ & * \\
\hline Epicatechin & $207.5 \pm 14.7 \mathrm{a}$ & $174.8 \pm 15.2 \mathrm{a}$ & $173.3 \pm 8.7 \mathrm{a}$ & * \\
\hline Procyanidin B1 & $108.6 \pm 17.1 \mathrm{~b}$ & $95.5 \pm 19.2 \mathrm{ab}$ & $57.0 \pm 3.1 \mathrm{a}$ & $*$ \\
\hline Procyanidin B2 & $570.1 \pm 20.5$ & $459.6 \pm 29.0$ & $577.2 \pm 48.3$ & NS \\
\hline Procyanidin trimer & $553.8 \pm 60.4$ & $484.7 \pm 45.2$ & $418.4 \pm 30.0$ & NS \\
\hline Procyanidin tetramer & $133.6 \pm 23.3 b$ & $82.5 \pm 15.7 \mathrm{a}$ & $62.4 \pm 4.0 \mathrm{a}$ & * \\
\hline Total flavan-3-ols & $1761.2 \pm 144.7$ & $1425.6 \pm 130.6$ & $1419.6 \pm 101.9$ & NS \\
\hline Quercetin-3-O-rutinoside & $30.7 \pm 5.97 b$ & $25.6 \pm 1.1 \mathrm{ab}$ & $18.3 \pm 2.0 \mathrm{a}$ & * \\
\hline Quercetin-3-O-galactoside & $259.4 \pm 35.4 \mathrm{~b}$ & $165.2 \pm 7.9 \mathrm{a}$ & $164.9 \pm 26.3 \mathrm{a}$ & * \\
\hline Quercetin-3-O-glucoside & $20.8 \pm 2.6 b$ & $15.1 \pm 1.3 \mathrm{ab}$ & $12.9 \pm 1.3 \mathrm{a}$ & * \\
\hline Quercetin-3-O-xyloside & $79.2 \pm 11.5 \mathrm{~b}$ & $51.2 \pm 4.4 \mathrm{a}$ & $45.7 \pm 3.0 \mathrm{a}$ & * \\
\hline Quercetin-3-O-arabinopyranoside & $41.2 \pm 4.7$ & $32.8 \pm 4.3$ & $29.7 \pm 2.6$ & NS \\
\hline Quercetin-3-arabinofuranoside & $197.1 \pm 12.9 \mathrm{~b}$ & $176.4 \pm 11.7 \mathrm{ab}$ & $149.3 \pm 15.4 \mathrm{a}$ & * \\
\hline Quercetin-3-O-rhamnoside & $735.4 \pm 99.9 \mathrm{~b}$ & $526.6 \pm 59.4 \mathrm{ab}$ & $495.3 \pm 47.6 \mathrm{a}$ & * \\
\hline Total flavonols & $1363.8 \pm 172.8 \mathrm{~b}$ & $992.9 \pm 89.9 \mathrm{ab}$ & $916.2 \pm 98.3 \mathrm{a}$ & * \\
\hline Phloretin-2'-O-(2-O-xylosyl) glucoside & $273.6 \pm 19.8$ & $252.7 \pm 21.8$ & $215.2 \pm 10.7$ & NS \\
\hline Phlorizin & $907.1 \pm 37.8$ & $876.7 \pm 75.8$ & $828.8 \pm 53.1$ & NS \\
\hline 3-hydroxyphloretin & $7783.3 \pm 828.7 \mathrm{~b}$ & $5788.1 \pm 533.8 \mathrm{a}$ & $5185.5 \pm 358.6 \mathrm{a}$ & * \\
\hline Total chalcones & $8963.7 \pm 886.3 b$ & $6917.4 \pm 631.4 \mathrm{a}$ & $6229 \pm 422.4 \mathrm{a}$ & * \\
\hline Cyanidin-3-galactoside & $68.6 \pm 5.1 \mathrm{~b}$ & $56.2 \pm 8.4 \mathrm{ab}$ & $45.1 \pm 1.7 \mathrm{a}$ & * \\
\hline Cyanidin-3-arabinoside & $6.9 \pm 0.7 \mathrm{~b}$ & $5.4 \pm 0.9 \mathrm{~b}$ & $2.7 \pm 0.6 \mathrm{a}$ & * \\
\hline Cyanidin-7-arabinoside & $5.1 \pm 0.5 \mathrm{~b}$ & $3.9 \pm 0.7 \mathrm{ab}$ & $2.6 \pm 0.1 \mathrm{a}$ & * \\
\hline Total anthocyanins & $80.6 \pm 6.3 b$ & $65.5 \pm 1.0 \mathrm{ab}$ & $50.4 \pm 2.4 \mathrm{a}$ & * \\
\hline
\end{tabular}

Treatments: N0 = sprayed with water only, N1 $=1.4 \mathrm{~kg} \mathrm{~N} \mathrm{ha}^{-1}, \mathrm{~N} 4=4 \mathrm{~kg} \mathrm{~N}^{-1}$. Different letters (a,b; NS, non-significant, ${ }^{*}$ significant difference at $p<0.05$ ) for each parameter denote statistically significant differences among treatments by LSD multiple range test.

A significant effect of low-dose urea sprayings was detected on almost all individual phenolic compounds. The highest levels of secondary metabolites were always measured in apples subject to N0 treatment and only slight differences were detected between N1 and N4 treatments. Decreased levels of phenolics impacted by high plant nitrogen status have been discussed in a study on tobacco model plants by Fritz et al. [34] who concluded that nitrate inhibits significant segments of phenylpropanoid metabolism. Contrary, low nitrogen levels typically lead to augmented accumulation of secondary metabolites, including phenylpropanoids and flavonoids $[18,33,37]$. Interestingly, the amounts of nitrogen applied in our study were much lower than those studied previously, and yet, negative effects on phenolic synthesis were still evident. For example, significantly higher levels of chlorogenic acid in N0 treatment are in line with the increased content of this carbon-rich phenolic acid reported by Fritz et al. [34]. A different justification of reduced levels of secondary metabolites in $\mathrm{N} 1$ and $\mathrm{N} 4$ treatments can be linked to the role of these compounds in plants. Many function as signaling and defense molecules against abiotic and biotic stress [38] and decreased levels in N1 and N4 treatments may correspond to an improved mineral status of the plants.

Although all phenolic groups were significantly affected by foliar urea sprayings the composition of anthocyanins can be considered most relevant for the producers as it directly affects the visual attributes of apple fruit. The lowest levels of total anthocyanins were measured in apples subject to $\mathrm{N} 4$ treatment which can be associated with colorimetrically determined fruit skin color parameters. In line with the results of our study, urea application decreased total anthocyanins in 'Gala' apples [17], pomegranate fruit [18], and grape berries [27]. The authors speculate that nitrogen excess down-regulated genes encoding enzymes associated with flavonoid biosynthesis, which also includes anthocyanins [39]. 
On the other hand, limited nitrogen availability leads to an increased accumulation of carbon-based secondary metabolites such as anthocyanins [40].

\subsection{Assimilatory Pigments}

Chlorophyll a and $\mathrm{b}$ were the prevalent chloroplast pigments in 'Topaz' fruit, followed by $\beta$-carotene, lutein, and $\alpha$-carotene (Table 4 ), which is in accordance with previous research on apple $[24,41]$. Low doses of foliar urea treatments caused a significant increase in total assimilatory pigments in apple skin which corresponds to higher chlorophyll and carotenoid levels measured in urea-sprayed 'Gala' apples [17]. Jakopic et al. [29] and Prsa et al. [42] also measured greater indexed chlorophyll content (leaf SPAD) in 'Golden Delicious' leaves fertilized with higher nitrogen doses. Similar effects of nitrogen application were reported on tomato [33,43] and mango fruit carotenoid composition [26].

Table 4. Assimilatory pigments ( $\mu \mathrm{g} \mathrm{g}^{-1} \mathrm{FW}$ ) of 'Topaz' apples subject to three urea treatments.

\begin{tabular}{ccccc}
\hline Compound & N0 & N1 & N4 & Significance \\
\hline Lutein & $0.30 \pm 0.03$ & $0.39 \pm 0.02$ & $0.31 \pm 0.01$ & NS \\
Chlorophyll b & $2.09 \pm 0.29$ & $2.77 \pm 0.29$ & $2.66 \pm 0.15$ & NS \\
Chlorophyll a & $2.50 \pm 0.27 \mathrm{a}$ & $4.22 \pm 0.35 \mathrm{~b}$ & $3.0 \pm 0.44 \mathrm{a}$ & $*$ \\
$\alpha$-carotene & $0.03 \pm 0.001 \mathrm{a}$ & $0.03 \pm 0.004 \mathrm{a}$ & $0.05 \pm 0.002 \mathrm{~b}$ & $*$ \\
$\beta$-carotene & $1.05 \pm 0.18$ & $1.23 \pm 0.30$ & $1.69 \pm 0.18$ & $\mathrm{NS}$ \\
Total assimilatory pigments & $5.97 \pm 0.77 \mathrm{a}$ & $8.64 \pm 0.96 \mathrm{~b}$ & $7.71 \pm 0.78 \mathrm{ab}$ & $*$ \\
\hline
\end{tabular}

Treatments: $\mathrm{N} 0=$ sprayed with water only, $\mathrm{N} 1=1.4 \mathrm{~kg} \mathrm{~N} \mathrm{ha}^{-1}, \mathrm{~N} 4=4 \mathrm{~kg} \mathrm{~N} \mathrm{ha}^{-1}$. Different letters (a,b; NS non-significant, * significant difference at $p<0.05)$ for each parameter denote statistically significant differences among treatments by LSD multiple range test.

\section{Conclusions}

Foliar application of urea is a common practice in apple orchards, particularly in conditions unfavorable for soil fertilization. Moreover, low levels of nitrogen are often incorporated in preharvest foliar sprays which are used to improve fruit quality, delay fruit ripening, or decrease postharvest fruit decay [11]. However, the present study displays negative impacts of low-doses of urea applied several times during the apple cell enlargement stage in the final stages of fruit development. The effect was particularly significant on the content of secondary metabolites, which are linked to many defense mechanisms in plants and importantly contribute to visual attributes (anthocyanins) or health-promoting properties (total phenolics content) of apple fruit. Although apple fruit size was positively affected by low-dose urea treatment primary as well as secondary metabolic profiles were more favorable in treatment with no addition of urea. It can be concluded that even minor levels of nitrogen (often present in foliar products used for enhancing fruit storage abilities), applied directly on the leaf at later stages of red apple fruit development adversely affect their color traits and composition of metabolites.

Author Contributions: Conceptualization, F.S. and R.V.; Methodology, J.J; Validation, T.S., V.S. and J.J.; Formal analysis, T.S.; Resources, R.V.; Data curation, T.S.; Writing — original draft preparation, J.J.; Writing—review and editing, V.S.; Visualization, T.S.; Supervision, R.V.; Project administration, R.V.; Funding acquisition, R.V. All authors have read and agreed to the published version of the manuscript.

Funding: This research was funded by Horticulture P4-0013-0481 supported by the Slovenian Research Agency (ARRS).

Institutional Review Board Statement: Not applicable.

Informed Consent Statement: Not applicable.

Data Availability Statement: The data presented in this study are available on request from the corresponding author. The data are not publicly available due to privacy.

Conflicts of Interest: The authors declare no conflict of interest. 


\section{References}

1. Von Bennewitz, E.; Cazanga-Solar, R.; Carrasco-Benavides, M.; Fredes, C.; Alba-Mejia, J.E.; Losak, T. Vegetative and productive responses of organic apple (Malus domestica L.) to fossilized red guano and a controlled-release fertilizer. Chil. J. Agric. Anim. Sci. 2017, 33, 213-220. [CrossRef]

2. Xia, G.L.; Cheng, L.; Lakso, A.N.; Goffinet, M.C. Effects of nitrogen supply on source-sink balance and fruit size of Gala apple trees. J. Am. Soc. Hortic. Sci. 2009, 134, 126-133. [CrossRef]

3. Shi, M.Z.; Xie, D.Y. Engineering of red cells in Arabidopsis thaliana and comparative genome-wide gene expression analysis of red cells versus wild-type cells. Planta 2011, 233, 787-805. [CrossRef] [PubMed]

4. Sklodowska, M.; Mikicinski, A.; Wielanek, M.; Kuzniak, E.; Sobiczewski, P. Phenolic profiles in apple leaves and the efficacy of selected phenols against fire blight (Erwinia amylovora). Eur. J. Plant Pathol. 2018, 151, 213-228. [CrossRef]

5. Solomakhin, A.A.; Blanke, M. Overcoming adverse effects of hailnets on fruit quality and microclimate in an apple orchard. J. Sci. Food Agric. 2007, 87, 2625-2637. [CrossRef]

6. Musacchi, S.; Serra, S. Apple fruit quality: Overview on pre-harvest factors. Sci. Hortic. 2018, 234, 409-430. [CrossRef]

7. Gu, K.D.; Wang, C.K.; Hu, D.G.; Hao, Y.J. How do anthocyanins paint our horticultural products? Sci. Hortic. 2019, 249 , 257-262. [CrossRef]

8. Kühn, B.F.; Bertelsen, M.; Sørensen, L. Optimising quality parameters of apple cv. 'Pigeon' by adjustment of nitrogen. Sci. Hortic. 2011, 129, 369-375. [CrossRef]

9. Lara, I. Preharvest foliar sprays and their effects on the postharvest quality of fruit. Stewart Postharvest Rev. 2013, 9, 1-12. [CrossRef]

10. Solhjoo, S.; Gharaghani, A.; Fallahi, E. Calcium and Potassium Foliar Sprays Affect Fruit Skin Color, Quality Attributes, and Mineral Nutrient Concentrations of 'Red Delicious' Apples. Int. J. Fruit Sci. 2017, 17, 358-373. [CrossRef]

11. Yu, X.M.; Wang, J.Z.; Nie, P.X.; Xue, X.M.; Wang, G.P.; An, M. Control efficacy of Ca-containing foliar fertilizers on bitter pit in bagged 'Fuji' apple and effects on the Ca and N contents of apple fruits and leaves. J. Sci. Food Agric. 2018, 98, 5435-5443. [CrossRef] [PubMed]

12. Fallahi, E.; Eichert, T. Principles and practices if foliar nutrients with an emphasis on nitrogen and calcium sprays in apple. J. Am. Soc. Hortic. Sci. 2013, 23, 542-547. [CrossRef]

13. Fernandez, V.; Sotiropoulus, T.; Brown, P.H. Foliar Fertilization: Scientific Principles and Field Practices, 1st ed.; International Fertilizer Industry Association: Paris, France, 2013; pp. 94-99, ISBN 9791092366006.

14. Sharma, L.K. Effect of nutrients sprays on growth, yield and fruit quality of apple under cold desert condition of Himachal Pradesh. J. Appl. Nat. Sci. 2016, 8, 297-300. [CrossRef]

15. De Angelis, V.; Sanchez, E.; Tognetti, J. Timing of Nitrogen Fertilization Influences Color and Anthocyanin Content of Apple (Malus domestica Borkh. cv 'Royal Gala') Fruits. Int. J. Fruit Sci. 2011, 11, 364-375. [CrossRef]

16. Wang, H.; Cheng, L. Differential Effects of Nitrogen Supply on Skin Pigmentation and Flesh Starch Breakdown of 'Gala' Apple. Hortscience 2011, 46, 1116-1120. [CrossRef]

17. Reay, P.F.; Fletcher, R.H.; Thomas, V.J.G. Chlorophylls, carotenoids and anthocyanin concentrations in the skin of 'Gala' apples during maturation and the influence of foliar applications of nitrogen and magnesium. J. Sci. Food Agric. 1998, 76, 63-71. [CrossRef]

18. Davarpanah, S.; Tehranifar, A.; Davarynenad, G. Effects of foliar nano-nitrogen and urea fertilizers on the physical and chemical properties of pomegranate (Punica granatum cv. Ardestani) fruit. HortScience 2017, 52, 288-294. [CrossRef]

19. Mikulic-Petkovsek, M.; Slatnar, A.; Stampar, F.; Veberic, R. The influence of organic/integrated production on the content of phenolic compounds in apple leaves and fruits in four different varieties over a 2-year period. J. Sci. Food Agric. 2010, 90, 66-78. [CrossRef]

20. Tomic, J.; Stampar, F.; Glisic, I.; Jakopic, J. Phytochemical assessment of plum (Prunus domestica L.) cultivars selected in Serbia. Food Chem. 2019, 299. [CrossRef]

21. Sircelj, H.; Batic, F. Evaluation of selected nutritional factors in Aposeris foetida (L.) Less. during the harvesting period. J. Appl. Bot. Food Qual. Angew. Bot. 2007, 81, 121-125.

22. Senica, M.; Veberic, R.; Grabnar, J.J.; Stampar, F.; Jakopic, J. Selected chemical compounds in firm and mellow persimmon fruit before and after the drying process. J. Sci. Food Agric. 2016, 96, 3140-3177. [CrossRef] [PubMed]

23. Robinson, T.L.; Schupp, J.; Fargione, M.; Osborne, J. Growing large 'Gala' apples. Compact Fruit Tree 2005, 38, 2-5.

24. Dar, J.A.; Wani, A.A.; Ahmed, M.; Nazir, R.; Zargar, S.M.; Javaid, K. Peel colour in apple (Malus $\times$ domestica Borkh.): An economic quality parameter in fruit market. Sci. Hortic. 2019, 244, 50-60. [CrossRef]

25. Wargo, J.M.; Merwin, I.A.; Watkins, C.B. Nitrogen fertilization, midsummer trunk girdling, and AVG treatments affect maturity and quality of 'Jonagold' apples. HortScience 2004, 39, 493-500. [CrossRef]

26. Nguyen, H.; Hofman, P.; Holmes, R.; Bally, I.; Stubbings, B.; Mcconchie, R. Effect of nitrogen on the skin colour and other quality attributes of ripe 'Kensington Pride' mango (Mangifera indica L.) fruit. J. Hortic. Sci. Biotechnol. 2004, 79, 204-210. [CrossRef]

27. Delgado, R.; Gonzalez, M.R.; Martin, P. Interaction effects of nitrogen and potassium fertilization on anthocyanin composition and chromatic features of Tempranillo grapes. J. Int. Sci. Vigne Vin 2006, 40, 141-150. [CrossRef]

28. Dolinski, M.A.; Dangelo, J.W.D.; Cuquel, F.L.; Motta, A.C.V.; De Mio, L.L.M. Quality peach produced in fertilizer doses of nitrogen and green pruning. Bragantia 2018, 77, 134-140. [CrossRef] 
29. Jakopic, J.; Veberic, R.; Zupancic, K.; Stampar, F. Influence of nitrogen on the contents of carbohydrates and organic acids in apples (Malus domestica Borkh.) cv. "Golden Delicious". Eur. J. Hortic. Sci. 2007, 72, 66-72.

30. Bizjak, J.; Mikulic-Petkovsek, M.; Stampar, F.; Veberic, R. Changes in Primary Metabolites and Polyphenols in the Peel of "Braeburn" Apples (Malus domestica Borkh.) during Advanced Maturation. J. Agric. Food Chem. 2013, 61, 10283-10292. [CrossRef]

31. Bat, K.B.; Vodopivec, B.M.; Eler, K.; Ogrinc, N.; Mulic, I.; Masuero, D.; Vrhovsek, U. Primary and secondary metabolites as a tool for differentiation of apple juice according to cultivar and geographical origin. LWT-Food Sci. Technol. 2018, 90, 238-245. [CrossRef]

32. Simmone, A.H.; Fuzere, J.M.; Simmone, E.; Hochmuth, R.C.; Marshall, M.R. Effects of nitrogen rates on chemical composition of yellow grape tomato grown in a subtropical climate. J. Plant Nutr. 2007, 30, 927-935. [CrossRef]

33. Benard, C.; Gautier, H.; Bourgaud, F.; Grasselly, D.; Navez, B.; Caris-Veyrat, C.; Weiss, M.; Genard, M. Effects of Low Nitrogen Supply on Tomato (Solanum lycopersicum) Fruit Yield and Quality with Special Emphasis on Sugars, Acids, Ascorbate, Carotenoids, and Phenolic Compounds. J. Agric. Food Chem. 2009, 57, 4112-4123. [CrossRef] [PubMed]

34. Fritz, C.; Palacios-Rojas, N.; Feil, R.; Stitt, M. Regulation of secondary metabolism by the carbon-nitrogen status in tobacco: Nitrate inhibits large sectors of phenylpropanoid metabolism. Plant J. 2006, 46, 533-548. [CrossRef] [PubMed]

35. Jakopic, J.; Slatnar, A.; Stampar, F.; Veberic, R.; Simoncic, A. Analysis of selected primary metabolites and phenolic profile of "Golden Delicious" apples from four production systems. Fruits 2012, 67, 377-386. [CrossRef]

36. Bizjak, J.; Weber, N.; Mikulic-Petkovsek, M.; Slatnar, A.; Stampar, F.; Alam, Z.; Stich, K.; Halbwirth, H.; Veberic, R. Influence of Phostrade Ca on Color Development and Anthocyanin Content of 'Braeburn' Apple (Malus domestica Borkh.). Hort. Sci. 2013, 48, 193-199. [CrossRef]

37. Lou, Y.; Baldwin, I.T. Nitrogen supply influences herbivore-induced direct and indirect defense and transcriptional response in Nicotiana attenuata. Plant Physiol. 2004, 135, 496-506. [CrossRef]

38. Slatnar, A.; Stampar, F.; Veberic, R. Influence of bicarbonate salts, used against apple scab, on selected primary and secondary metabolites in apple fruit and leaves. Sci. Hortic. 2012, 143, 197-204. [CrossRef]

39. Stefanelli, D.; Goodwin, I.; Jones, R. Minimal nitrogen and water use in horticulture: Effects on quality and content of selected nutrients. Food Res. Int. 2010, 43, 1833-1843. [CrossRef]

40. Jaakola, L. New insights into the regulation of anthocyanin biosynthesis in fruits. Trends Plant Sci. 2013, 18, 477-483. [CrossRef]

41. Schaeffer, S.M.; Christian, R.; Castro-Velasquez, N.; Hyden, B.; Lynch-Holm, V.; Dhingra, A. Comparative ultrastructure of fruit plastids in three genetically diverse genotypes of apple (Malus $\times$ domestica Borkh.) during development. Plant Cell Rep. 2017, 36, 1627-1640. [CrossRef]

42. Prsa, I.; Stampar, F.; Vodnik, D.; Veberic, R. Influence of nitrogen on leaf chlorophyll content and photosynthesis of 'Golden Delicious' apple. Acta Agric. Scand. B Soil Plant Sci. 2007, 57, 283-289. [CrossRef]

43. Dumas, Y.; Dadomo, M.; Di Lucca, G.; Grolier, P. Effects of environmental factors and agricultural techniques on antioxidant content of tomatoes. J. Sci. Food Agric. 2003, 83, 369-382. [CrossRef] 